University of Nebraska - Lincoln

DigitalCommons@University of Nebraska - Lincoln

USDA National Wildlife Research Center - Staff Publications
U.S. Department of Agriculture: Animal and Plant Health Inspection Service

2013

\title{
Bird damage to select fruit crops: The cost of damage and the benefits of control in five states
}

\author{
Aaron M. Anderson \\ USDA/APHIS/WS National Wildlife Research Center, aaron.m.anderson@aphis.usda.gov \\ C.A. Lindell \\ Michigan State University, lindellc@msu.edu \\ Karen M. Moxcey \\ USDA/APHIS/WS, Karen.M.Moxcey@aphis.usda.gov \\ W.F. Siemer \\ Cornell University, wfs1@cornell.edu
}

George M. Linz

USDA/APHIS/WS National Wildlife Research Center, george.m.linz@aphis.usda.gov

See next page for additional authors

Follow this and additional works at: https://digitalcommons.unl.edu/icwdm_usdanwrc

Anderson, Aaron M.; Lindell, C.A.; Moxcey, Karen M.; Siemer, W.F.; Linz, George M.; Curtis, P.D.; Carroll, J.E.; Burrows, C.L.; Boulanger, Jason R.; Steensma, K.M.M.; and Shwiff, Stpehanie A., "Bird damage to select fruit crops: The cost of damage and the benefits of control in five states" (2013). USDA National Wildlife Research Center - Staff Publications. 1221.

https://digitalcommons.unl.edu/icwdm_usdanwrc/1221

This Article is brought to you for free and open access by the U.S. Department of Agriculture: Animal and Plant Health Inspection Service at DigitalCommons@University of Nebraska - Lincoln. It has been accepted for inclusion in USDA National Wildlife Research Center - Staff Publications by an authorized administrator of DigitalCommons@University of Nebraska - Lincoln. 


\section{Authors}

Aaron M. Anderson, C.A. Lindell, Karen M. Moxcey, W.F. Siemer, George M. Linz, P.D. Curtis, J.E. Carroll, C.L. Burrows, Jason R. Boulanger, K.M.M. Steensma, and Stpehanie A. Shwiff 


\title{
Bird damage to select fruit crops: The cost of damage and the benefits of control in five states
}

\author{
A. Anderson ${ }^{\mathrm{a}, *}$, C.A. Lindell ${ }^{\mathrm{b}}$, K.M. Moxcey ${ }^{\mathrm{a}}$, W.F. Siemer ${ }^{\mathrm{c}}$, G.M. Linz $^{\mathrm{d}}$, P.D. Curtis ${ }^{\mathrm{c}}$, \\ J.E. Carroll ${ }^{\text {c }}$, C.L. Burrows ${ }^{\text {e }}$, J.R. Boulanger ${ }^{c}$, K.M.M. Steensma ${ }^{\text {f }}$, S.A. Shwiff ${ }^{\text {a }}$ \\ ${ }^{a}$ USDA/APHIS/WS National Wildlife Research Center, 4101 LaPorte Ave., Fort Collins, CO 80521, USA \\ ${ }^{\mathrm{b}}$ Michigan State University, 1405 S. Harrison Rd., East Lansing, MI 48823, USA

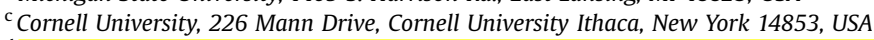 \\ ${ }^{\mathrm{d}}$ USDA/APHIS/WS National Wildlife Research Center, 2110 Miriam Circle, Suite B, Bismarck, ND 58501, USA \\ ${ }^{\mathrm{e}}$ Washington State University 1000 N Forest Street, Suite 201, Bellingham, WA 98225, USA \\ ${ }^{\mathrm{f}}$ Trinity Western University, 7600 Glover Road, Langley, BC V2Y 1Y1, Canada
}

\section{A R T I C L E I N F O}

\section{Article history:}

Received 13 March 2013

Received in revised form

21 May 2013

Accepted 22 May 2013

Keywords:

Fruit crops

Bird damage

Survey

Economics

Pest management

\begin{abstract}
A B S T R A C T
Fruit loss to birds is a long-standing and costly problem for many producers. We conducted a survey of Honeycrisp apple, blueberry, cherry, and wine grape growers in California, Michigan, New York, Oregon, and Washington to estimate costs of bird damage and benefits of bird damage management. We also assessed grower perceptions of impacts on profits and effectiveness of bird management techniques. Current yield-loss estimates provided by growers and market price data were used to monetize current bird damage in each crop and growing region. Data on expected damage without management were used to estimate the benefits of bird damage management as it is currently being employed in the different crops and growing regions. We estimated that current bird damage costs per hectare ranged from \$104 in Oregon tart cherries to \$7267 in Washington Honeycrisp apples. Estimated benefits of bird management ranged from $\$ 299$ per hectare in Oregon tart cherries to $\$ 36,851$ in California blueberries. Aggregate bird damage in the five crops and states was estimated at $\$ 189$ million, and the aggregate benefits of managing that damage were estimated at $\$ 737$ million to $\$ 834$ million. Growers viewed most techniques for bird damage management as ineffective, or only slightly effective, and a majority of blueberry and sweet cherry growers viewed bird damage as having a significant impact on profits. Enhancing the effectiveness of bird damage management would increase both the efficiency and profitability of fruit production.
\end{abstract}

Published by Elsevier Ltd.

\section{Introduction}

The US is one of the top five fruit-producing nations in the world, accounting for over 29 million metric tons of production in 2009 (FAO, 2012; USDA ERS, 2011). Annual cash receipts from US fruit production currently exceed $\$ 15$ billion, making fruit agriculture an important sector of the US economy. Rising incomes,

\footnotetext{
* Corresponding author. Tel.: +1970266 6264.

E-mail addresses: aaron.m.anderson@aphis.usda.gov, Aaron.M.Anderson@ aphis.usda.gov (A. Anderson), lindellc@msu.edu (C.A. Lindell), Karen.M.Moxcey@ aphis.usda.gov (K.M. Moxcey), wfs1@cornell.edu (W.F. Siemer), george.m.linz@ aphis.usda.gov (G.M. Linz), pdc1@cornell.edu (P.D. Curtis), jec3@cornell.edu (J.E. Carroll), cburrows@wsu.edu (C.L. Burrows), jrb69@cornell.edu (J.R. Boulanger), Steensma@twu.ca (K.M.M. Steensma), Stephanie.A.Shwiff@ aphis.usda.gov (S.A. Shwiff).
}

both domestic and foreign, as well as better transportation technologies and growing awareness of health and nutrition, will only serve to increase the importance of fruit agriculture to the US economy. Thus, addressing threats posed by fruit crop pests and improving productivity and profitability is of great economic and social importance.

Fruit loss to birds is a long-standing and costly problem (Virgo, 1971; Dolbeer et al., 1994; Simon, 2008) affecting producers across the globe (Somers and Morris, 2002; Ahmad, 2010; Ribot et al., 2011). USDA NASS (1999) reported that US growers lose tens of millions of dollars each year through direct losses and oftenineffective efforts to deter birds, although the study was limited to two crops and seven states. In addition to outright consumption, birds damage fruit, leading to increased susceptibility to other pests and pathogens, and reduced product quality (Pritts, 2001; Duffy and Schaffner, 2002; Holb and Scherm, 2008). 
The economics of bird damage to fruit crops has received relatively little research attention compared to other agricultural pest problems (Gebhardt et al., 2011). Yet for many producers the impacts can be severe and management costly. Previous research on bird damage is mostly comprised of individual studies on either a single bird species or multiple species impacting a single crop (Crase et al., 1976; Hothem et al., 1981; Gadd, 1996; Cummings et al., 2005; Berge et al., 2007; Delwiche et al., 2007), or a single species impacting multiple crops (DeHaven, 1974), and thus a limited focus. A multi-crop, multi-region analysis allows investigation of the broader impact of bird pests, permits examination of damage differences between regions, and provides a better assessment of the benefits of employing various methods for bird damage management. A more comprehensive study would also allow growers to choose more effective management techniques and allow policymakers to make better-informed decisions about regulation and resource allocation. Few studies have attempted to evaluate multiple pest species' damage to multiple crops (Razee, 1976; USDA NASS, 1999; USDA NASS, 2002; Hueth et al., 1997; Gebhardt et al., 2011).

Our objective was to estimate bird damage to Honeycrisp apples, wine grapes, blueberries, and sweet and tart cherries in five important fruit-growing regions within the US. California (CA), Michigan (MI), New York (NY), Oregon (OR), and Washington (WA) together are responsible for over 70\% of U.S. fruit production (USDA ERS, 2012). All five states produce apples (although Honeycrisp apple production is negligible in California and Oregon), wine grapes, blueberries, and sweet cherries, and four of the five states also produce tart cherries (USDA NASS, 2012b), allowing for regional comparisons. All of these crops are susceptible to bird damage and the states represent a range of production systems and potential bird pests. While planning the project we talked with numerous growers and extension personnel about the crops to include in the survey. Honeycrisp was singled-out because these individuals expressed a strong interest in the variety because of its perceived high susceptibility to bird damage and the high financial losses of damage given that it is a fresh market apple.

We surveyed fruit growers to provide data on the current threat posed by bird damage, as well as the benefits of mitigation efforts. Solicitation of growers' estimates of current damage and their expectations of the extent of damage without management allowed estimation of the benefits of bird management as it is currently being used. Additionally, both the current cost of bird damage and the benefits of management were monetized based on recent market prices. Monetization of these estimates allows comparison not only across growing regions, but also across the different crops. Results provide important information to policymakers, scientists, growers, and other stakeholders by highlighting those crops and regions where bird damage poses the most severe threat to grower profitability.

\section{Methods}

\subsection{Survey instrument}

The survey instrument consisted of 21 questions that solicited information about the locations and size of the grower's farm, growers' level of fruit production experience, production area and yield data for the crops of interest, bird damage, bird management methods, and estimated costs for bird damage management. The instrument is available from the authors by request.

\subsection{Survey implementation}

Members of the Human Dimensions Research Unit (HDRU) at Cornell University assisted with survey implementation. Members of the research team suggested potential groups (e.g. New York Apple Association) that might have membership lists containing fruit growers in the target audiences in each state. HDRU staff and other members of the project team contacted those groups and obtained mailing lists as possible or secured cooperation from groups to complete survey implementation on behalf of the study team. Ultimately, a total of 17 groups agreed to participate at some level: 8 groups provided a mailing list for use by HDRU, 5 groups would not release their mailing lists but agreed to implement a mail survey to their members, and another 4 groups would not release their mailing lists but agreed to conduct a web-based survey of their members.

All survey mailings were completed between March 5 and May 1, 2012 (Table 1). Members of all groups received an identical questionnaire and similar cover letters. In 4 of 5 mail surveys implemented by HDRU, members of each sample were contacted up to four times (i.e., (1) an initial letter and questionnaire, (2) a reminder letter, (3) a third reminder letter and replacement questionnaire, and (4) a final reminder about one week after the third mailing). In one mail survey implemented by HDRU, and all mail surveys implemented on behalf of the research team, nonrespondents received up to three mailings (i.e., (1) an initial letter and questionnaire, (2) a reminder letter, and (3) a final reminder letter and replacement questionnaire $1-2$ weeks after the follow-

Table 1

Survey method, source of survey implementation, and number of contacts, by state and fruit crop.

\begin{tabular}{|c|c|c|c|c|c|}
\hline State & Targeted growers & Method & Implementor & \# of contacts & Dates of implementation \\
\hline $\mathrm{CA}$ & Blueberries & Web & California Blueberry Commission & 3 & March 15-April 5 \\
\hline CA & Cherries & Mail & California Cherry Advisory Board & 3 & March 15-April 5 \\
\hline $\mathrm{CA}$ & Grapes & Mail & HDRU & 3 & April 3-May 1 \\
\hline MI & Apples & Mail & Michigan Apple Committee & 3 & March 13-April 3 \\
\hline MI & Blueberries & Mail & Ottawa County MSU Extension & 3 & March 13-April 3 \\
\hline MI & Cherries & Mail & HDRU & 4 & March 5-April 2 \\
\hline MI & Grapes & Mail & HDRU & 4 & March 5-April 2 \\
\hline NY & Apples/Cherries & Mail & New York Apple Association & 3 & March 13-April 10 \\
\hline NY & Blueberries & Mail & HDRU & 4 & March 5-April 2 \\
\hline NY & Grapes & Mail & HDRU & 4 & March 5-April 2 \\
\hline OR & Apples & Mail & Columbia River Growers-Shippers Assn. & 3 & March 13-April 3 \\
\hline OR & Blueberries & Web & Oregon Blueberry Commission & 3 & March 16-April 6 \\
\hline OR & Cherries & Mail & Oregon Sweet Cherry Commission & 3 & March 13-April 3 \\
\hline OR & Grapes & Web & Oregon Winegrowers Association & 3 & March 16-April 6 \\
\hline WA & Apples/Cherries & Mail & Good Fruit Grower Magazine & 3 & March 13-April 3 \\
\hline WA & Blueberries & Mail & Washington Blueberry Commission & 3 & Mar 20-April 10 \\
\hline WA & Grapes & Web & WSU Viticulture \& Enology Program & 3 & March 13-April 3 \\
\hline
\end{tabular}


up reminder letter). Cooperating groups eliminated the final reminder mailing to reduce implementation burden on their staff. The total sample size for all 13 mail surveys was 7666 . To encourage survey response, all mail survey implementation incorporated several characteristics of the Dillman (2000) Total Design Method, including a brief, respondent-friendly questionnaire, multiple contacts by first-class mail, and cover letter elements that personalized correspondence.

The Survey Research Institute at Cornell University (SRI) was contracted by HDRU to conduct telephone surveys with nonrespondents in four survey groups for which the investigators had contact information: Michigan cherry and wine grape growers, and New York blueberry and wine grape growers. The nonrespondent interview contained a few questions to assess whether respondents differed from non-respondents on key traits (e.g., whether they grew the target fruit crops, whether they had experienced bird damage in 2011).

HDRU staff worked with the Survey Research Institute (SRI) at Cornell University to adapt the mail survey instrument for use in a web-based format. The four groups who agreed to assist with web survey implementation were provided with cover letters for up to three email contacts with their members. The cover letters included a link to a secure website where growers could complete the questionnaire. Group representatives told HDRU staff that email contacts went out between March 15 and April 6. The website for data collection was closed on May 30th, 2012. The total estimated sample size for all five web-based surveys was 1593.

\subsection{Estimating costs of damage and benefits of management}

We designed three questions to provide information for estimating the economic impact of bird damage and the benefits of management. First, we asked growers to estimate the percentage of their production they lost (yield-loss) to birds in the previous year. Second, we asked growers to report their expectation of consequences for bird damage on their property if no attempt was made by any grower in the region to control damage. Finally, we asked growers how they believed damage levels would change if they made no attempt to control damage on their property, but other regional growers maintained current management practices. It is likely that the amount of damage in absence of management would vary depending on the extent of management on other farms in the region. By soliciting growers' expectation of damage levels without management in two different ways, we captured alternative expectations based on different assumptions about the level of management on other farms in the region.

Yield-loss averages and yield savings due to bird management in each crop and state were calculated based on survey responses. By comparing yield-loss with and without management, the benefits (yield savings) of bird damage management can be estimated. Benefits are a function of the value of the crop protected, the level of damage that would occur without control, and the effectiveness of current management techniques. Current yield-loss estimates and management-benefit estimates for blueberries, cherries, and wine grapes in each state were monetized based on state-specific average price, production area, and production data from 2008 to 2010 from USDA ERS (2011). It is important to present damage in monetary terms if the burden of bird damage is to be compared across crops or regions. Different crops are valued at different amounts, and prices can also vary by region. Thus, equal yield-loss does not necessarily imply equivalent burden on growers. Little data on Honeycrisp prices were readily available so we assumed Honeycrisp prices were $\$ 1.03$ per pound in all states (WSU Extension, 2011). Per-hectare yield estimates for Honeycrisp apples were assumed equal to average all-apple yield in each state, and total production estimates were formed by weighting total apple production by the ratio of the Honeycrisp production area to total apple production area (USDA NASS, 2006a; USDA NASS, 2006b; USDA NASS, 2012a; WSU, 2011).

\section{Results}

\subsection{Sample sizes}

In total, 89 participants completed the web-based survey instrument; an additional 23 participants returned uncompleted questionnaires. The low response rate precluded inclusion of webbased survey data in this analysis. However, we received 2353 completed mail-based questionnaires, resulting in a $30.7 \%$ response rate (Table 2). Most (67.6\%) respondents grew wine grapes, blueberries, cherries, or Honeycrisp apples, resulting in a final sample size of 1590 . A total of 1572 responses were from CA $(22.5 \%)$, MI (28.2\%), NY (25.2\%), OR (7.5\%), or WA (16\%).

It was not possible for us to thoroughly examine potential nonresponse, because we were not given access to contact information for growers in most of the groups surveyed. We did have information sufficient to complete follow-up telephone interviews with samples of nonrespondents in four groups: New York grape growers $(n=75)$, Michigan grape growers $(n=50)$, Michigan cherry growers $(n=50)$, and New York blueberry growers $(n=28)$. These interviews suggest that nonresponse was highest in the groups that contained the largest proportions of non-fruit-growing members. For example, only 33\% of nonrespondents, and $41 \%$ of respondents in the New York wine grape mailing list had actually grown wine grapes in 2011 (response rate for the New York grape mailing list was $45 \%$ ). On the other hand, $82.1 \%$ of nonrespondents,

Table 2

Number of surveys and response rates by state and crop.

\begin{tabular}{|c|c|c|c|c|c|c|}
\hline State & Targeted growers & Surveys mailed & Usable returns & Undeliverable & Unusable & Response rate \\
\hline All & All & 7666 & 2353 & 262 & 51 & $31.70 \%$ \\
\hline $\mathrm{CA}$ & Cherries & 739 & 133 & 33 & 0 & $18.80 \%$ \\
\hline CA & Grapes & 580 & 234 & 1 & 1 & $40.40 \%$ \\
\hline MI & Apples & 853 & 190 & 3 & 6 & $22.40 \%$ \\
\hline MI & Blueberries & 611 & 179 & 41 & 5 & $31.40 \%$ \\
\hline MI & Cherries & 392 & 129 & 21 & 1 & $34.80 \%$ \\
\hline MI & Grapes & 260 & 102 & 16 & 1 & $41.80 \%$ \\
\hline NY & Apples/cherries & 613 & 254 & 6 & 1 & $41.80 \%$ \\
\hline NY & Blueberries & 160 & 77 & 21 & 2 & $55.40 \%$ \\
\hline NY & Grapes & 950 & 391 & 89 & 16 & $45.40 \%$ \\
\hline OR & Apples & 30 & 0 & 0 & 0 & $0.00 \%$ \\
\hline OR & Cherries & 328 & 126 & 5 & 3 & $39.00 \%$ \\
\hline WA & Apples/Cherries & 2000 & 472 & 23 & 15 & $23.90 \%$ \\
\hline WA & Blueberries & 150 & 53 & 3 & 0 & $36.10 \%$ \\
\hline
\end{tabular}


and $85.7 \%$ of respondents in the NY blueberry mailing list had actually grown blueberries in 2011 (response rate for the NY blueberry mailing list was 55\%).

\subsection{Survey results}

Most respondents $(n=1541)$ provided the number of hectares of fruit crops on their farms in 2011. Farms had 66 ha of fruit crops on average, and answers ranged from 0.04 to 3480 ha. Respondents had been farming an average of 31.9 years $(S D=18.8)$ and $71.6 \%$ of those surveyed said that farming was their primary occupation (Table 3). Growers described which damage-management methods they used (Fig. 1) and reported the effectiveness of the various methods of reducing bird damage (Fig. 2). We report the average percent of the production area on which the various types of bird management were used (Table 4), and the growers' qualitative assessment of the effects of bird damage on profit (Fig. 3). In order to determine which birds were causing the most damage, we implemented a scoring system to rank each species (Table 5). A species that was ranked first by a respondent was assigned three points, the second-ranked species two points, and the third-ranked species one point. Note that the rank of certain species (e.g. Wild Turkey) may be biased by the ease of species identification.

\subsection{Economic analysis}

Responses for each of the three questions that provide the data for the economic analysis that were beyond two standard deviations from the mean response for each crop were removed from the sample due to the possibility that these responses represented growers who misinterpreted the question, or intentionally misrepresented damage (Table 6). Unreported sensitivity analysis confirmed that removal of these observations had little effect on the results. New York growers report the highest yield-loss when averaging (unweighted) across the five crops, and averaging across states implies that sweet cherry growers incur the highest yield-

Table 3

Demographic information of survey respondents by state.

\begin{tabular}{lllll}
\hline & $\begin{array}{l}\text { Number of } \\
\text { surveys }\end{array}$ & $\begin{array}{l}\text { Average fruit crop } \\
\text { production area (ha) }\end{array}$ & $\begin{array}{l}\text { Average years } \\
\text { farming }\end{array}$ & $\begin{array}{l}\text { Farming is primary } \\
\text { occupation }\end{array}$ \\
\hline CA & 353 & 123.64 & 31.19 & $75.3 \%$ \\
MI & 443 & 54.92 & 32.22 & $71.3 \%$ \\
NY & 396 & 32.82 & 34.98 & $72.3 \%$ \\
OR & 118 & 31.93 & 27.56 & $66.1 \%$ \\
WA & 252 & 75.80 & 29.56 & $68.6 \%$ \\
\hline
\end{tabular}

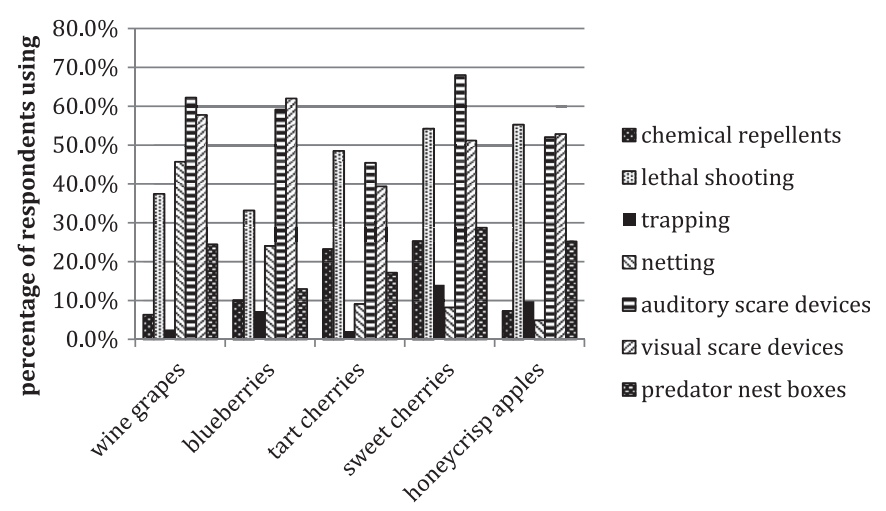

Fig. 1. Percentage of growers using bird damage management methods by crop in California, Michigan, New York, Oregon, and Washington during 2012.

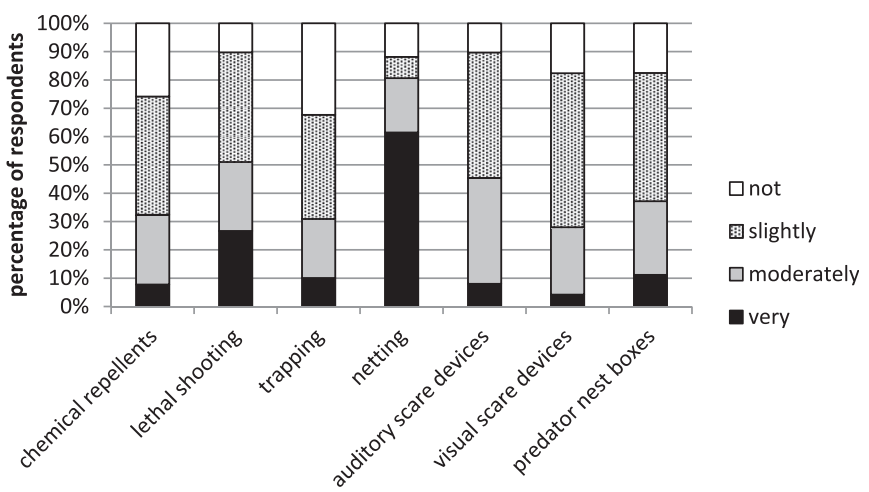

Fig. 2. Growers' perception of management effectiveness to control bird damage in five fruit crops.

Table 4

Percent of fruit production area on which bird control used.

\begin{tabular}{lrllll}
\hline & Blueberry & Wine grape & $\begin{array}{l}\text { Honeycrisp } \\
\text { apple }\end{array}$ & $\begin{array}{l}\text { Sweet } \\
\text { cherry }\end{array}$ & Tart cherry \\
\hline CA & $100.0 \%$ & $49.9 \%$ & - & $78.7 \%$ & - \\
MI & $71.3 \%$ & $77.8 \%$ & $49.2 \%$ & $70.6 \%$ & $39.9 \%$ \\
NY & $86.2 \%$ & $63.6 \%$ & $41.1 \%$ & $87.2 \%$ & $78.8 \%$ \\
OR & $63.0 \%$ & $76.5 \%$ & $30.0 \%$ & $71.4 \%$ & $51.7 \%$ \\
WA & $89.1 \%$ & $65.8 \%$ & $75.3 \%$ & $88.1 \%$ & $81.3 \%$ \\
\hline
\end{tabular}

loss (Table 7). The estimate of $31.4 \%$ yield-loss in New York sweet cherries drives both of these results. Oregon growers suffered the least yield-loss, and Honeycrisp apple growers reported a lower percentage yield-loss than growers of other crops. The estimates of yield-loss by crop and state, in combination with price and production data, were used to calculate the current costs of bird damage given current method of control (Table 8). The estimates of the benefits (yield savings) of bird management are presented in both a per-hectare basis and statewide basis (Table 9 ). The low and high estimates were derived from the difference in responses between the two questions that solicited damage estimates when no management was used. For some crops and states, growers expected lack of any bird management in the region to result in more damage than only lack of local bird management; for other crops and states growers expected the opposite. This inconsistency is likely due to the considerable uncertainty about the true result of a lack of any bird management in the region.

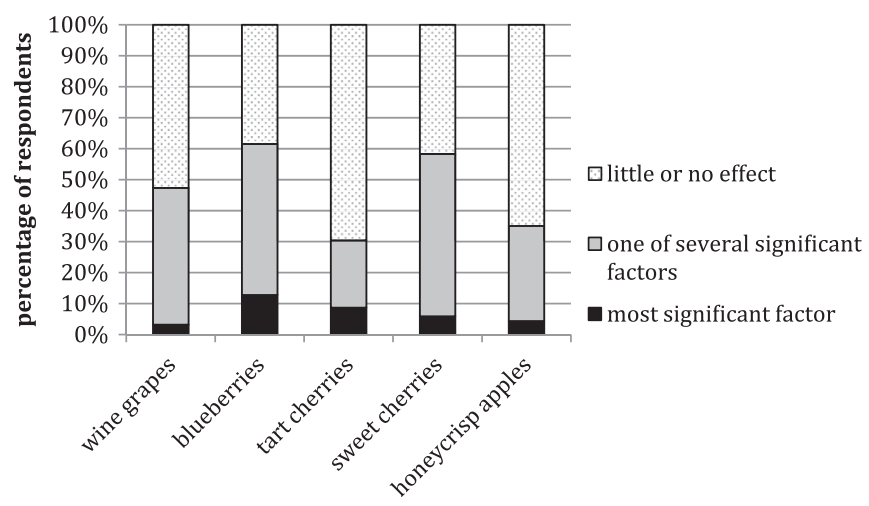

Fig. 3. Subjective assessment of profit impacts of bird damage to fruit crops. 
Table 5

Ranking of bird species responsible for fruit damage in five states.

\begin{tabular}{|c|c|c|c|c|c|c|c|c|c|}
\hline Blueberry & & Wine grape & & Honeycrisp apple & & Sweet cherry & & Tart cherry & \\
\hline American Robin ${ }^{\mathrm{a}}$ & 348 & European Starling & 642 & American Crow $^{\mathrm{e}}$ & 432 & American Robin & 821 & American Robin & 213 \\
\hline European Starling ${ }^{\mathrm{b}}$ & 335 & American Robin & 262 & European Starling & 135 & European Starling & 820 & European Starling & 179 \\
\hline Blackbirds ${ }^{c}$ & 201 & Wild Turkey $^{\mathrm{d}}$ & 200 & Wild Turkey & 120 & American Crow & 400 & American Crow & 144 \\
\hline
\end{tabular}

a Turdus migratorius.

b Sturnus vulgaris.

c This category could include one of several species including the Red-winged Blackbird, Agelaius phoeniceus, or potentially misidentified European Starlings.

d Meleagris gallopavo.

e Corvus brachyrhynchos.

\section{Discussion and conclusion}

We present results in two ways; damage per-hectare highlights the relative burden on growers of each crop within each state, while damage across the entire production area highlights the relative burden placed on the broader economies. Yield-loss and economic impacts caused by birds, as well as the benefits of managing bird damage, vary considerably by crop and growing region. Blueberry and Honeycrisp apple growers tended to suffer the largest losses from bird damage on a per-hectare basis. However, when considering the amount of production of each crop that occurs in the five states, sweet cherries and wine grapes have the highest amounts of aggregate monetary damage. The benefits of current bird damage management were estimated to be highest in blueberry and Honeycrisp production. From an aggregate standpoint, the benefits (yield savings) of bird damage management were greatest for California wine grape and Washington Honeycrisp apple and sweet cherry production; not necessarily because growers in these regions face a relatively high threat from birds, but instead because production is heavily concentrated in these regions.

Table 6

Number of responses by crop and state with the number of outliers removed in parentheses.

\begin{tabular}{lcccrr}
\hline \multicolumn{7}{c}{ Blueberry } & Wine grape & $\begin{array}{l}\text { Honeycrisp } \\
\text { apple }\end{array}$ & $\begin{array}{l}\text { Sweet } \\
\text { cherry }\end{array}$ & Tart cherry \\
\hline \multicolumn{7}{c}{ Current damage question (\#6) } \\
CA & $4(0)$ & $206(2)$ & - & $113(1)$ & - \\
MI & $118(5)$ & $76(2)$ & $117(2)$ & $137(5)$ & $119(3)$ \\
NY & $105(3)$ & $143(3)$ & $131(3)$ & $88(0)$ & $43(2)$ \\
OR & $11(0)$ & $5(0)$ & $5(0)$ & $105(2)$ & $4(0)$ \\
WA & $41(0)$ & $19(0)$ & $50(1)$ & $165(6)$ & $3(0)$ \\
Damage without control question (\#12,13)(low) & \\
CA & $3(0)$ & $122(0)$ & - & $74(0)$ & - \\
MI & $61(0)$ & $58(0)$ & $57(2)$ & $84(0)$ & $54(2)$ \\
NY & $70(0)$ & $89(0)$ & $54(3)$ & $67(0)$ & $32(0)$ \\
OR & $9(0)$ & $4(0)$ & $5(0)$ & $73(2)$ & $3(0)$ \\
WA & $29(0)$ & $14(0)$ & $42(0)$ & $137(0)$ & $3(0)$ \\
Damage without control question (\#12,13)(high) & \\
CA & $5(0)$ & $134(0)$ & - & $78(2)$ & - \\
MI & $64(0)$ & $57(0)$ & $59(1)$ & $90(0)$ & $59(2)$ \\
NY & $81(0)$ & $89(0)$ & $54(2)$ & $67(0)$ & $31(0)$ \\
OR & $9(0)$ & $4(0)$ & $4(0)$ & $78(2)$ & $2(0)$ \\
WA & $31(0)$ & $14(0)$ & $42(0)$ & $144(0)$ & $3(0)$ \\
\hline
\end{tabular}

Table 7

Current yield-loss due to bird damage in fruit production by crop and state.

\begin{tabular}{lrllrc}
\hline & Blueberry & Wine grape & $\begin{array}{l}\text { Honeycrisp } \\
\text { apple }\end{array}$ & $\begin{array}{l}\text { Sweet } \\
\text { cherry }\end{array}$ & Tart cherry \\
\hline CA & $3.8 \%$ & $2.9 \%$ & - & $5.2 \%$ & - \\
MI & $10.5 \%$ & $9.2 \%$ & $3.5 \%$ & $13.3 \%$ & $4.8 \%$ \\
NY & $11.7 \%$ & $5.6 \%$ & $4.7 \%$ & $31.4 \%$ & $9.4 \%$ \\
OR & $18.2 \%$ & $4.9 \%$ & $0.4 \%$ & $4.8 \%$ & $3.0 \%$ \\
WA & $9.7 \%$ & $7.6 \%$ & $7.4 \%$ & $8.9 \%$ & $26.7 \%$ \\
\hline
\end{tabular}

On a per-hectare basis, California blueberry growers derive the largest benefits from their use of bird management methods, and Oregon tart cherry growers derive the lowest benefits. However, both of these estimates were based on very small sample sizes. Of the crops and states with more than thirty responses, Washington Honeycrisp growers benefit the most from bird management and Michigan tart cherry growers benefit the least. These are particularly important results because they represent the revenue gains to growers from the use of bird management.

Table 8

Current bird damage in fruit production by crop and state.

\begin{tabular}{|c|c|c|c|c|c|}
\hline & Blueberry & Wine grape & $\begin{array}{l}\text { Honeycrisp } \\
\text { apple }\end{array}$ & $\begin{array}{l}\text { Sweet } \\
\text { cherry }\end{array}$ & Tart cherry \\
\hline \multicolumn{6}{|c|}{ Damage - per hectare } \\
\hline CA & $\$ 2063$ & $\$ 247$ & & $\$ 1129$ & \\
\hline MI & $\$ 1871$ & $\$ 430$ & $\$ 1885$ & $\$ 746$ & $\$ 225$ \\
\hline NY & $\$ 1609$ & $\$ 230$ & $\$ 3892$ & $\$ 5197$ & $\$ 430$ \\
\hline OR & $\$ 4571$ & $\$ 573$ & $\$ 299$ & $\$ 746$ & $\$ 104$ \\
\hline WA & $\$ 2444$ & $\$ 946$ & $\$ 7267$ & $\$ 2417$ & $\$ 3042$ \\
\hline \multicolumn{6}{|c|}{ Damage - statewide } \\
\hline CA & $\$ 2,649,875$ & $\$ 49,099,613$ & - & $\$ 12,378,205$ & - \\
\hline MI & $\$ 14,052,402$ & $\$ 2,472,268$ & $\$ 1,498,906$ & $\$ 2,090,723$ & $\$ 2,251,261$ \\
\hline NY & $\$ 585,753$ & $\$ 3,452,595$ & $\$ 1,373,583$ & $\$ 1,188,371$ & $\$ 261,530$ \\
\hline OR & $\$ 11,238,095$ & $\$ 2,675,986$ & $\$ 23,454$ & $\$ 3,253,331$ & $\$ 27,062$ \\
\hline WA & $\$ 4,653,105$ & $\$ 12,892,063$ & $\$ 26,758,486$ & $\$ 31,974,215$ & $\$ 1,843,721$ \\
\hline
\end{tabular}

Table 9

Benefits (yield savings) of bird control in fruit production by crop and state.

\begin{tabular}{llllll}
\hline \multicolumn{1}{c}{ Blueberry } & Wine grape & $\begin{array}{l}\text { Honeycrisp } \\
\text { apple }\end{array}$ & $\begin{array}{l}\text { Sweet } \\
\text { cherry }\end{array}$ & Tart cherry \\
\hline (low) per hectare & & & & \\
CA & $\$ 34,842$ & $\$ 1665$ & & $\$ 1737$ & - \\
MI & $\$ 4398$ & $\$ 1463$ & $\$ 4905$ & $\$ 1315$ & $\$ 356$ \\
NY & $\$ 5552$ & $\$ 1258$ & $\$ 6788$ & $\$ 4668$ & $\$ 1559$ \\
OR & $\$ 4522$ & $\$ 3585$ & $\$ 1873$ & $\$ 2221$ & $\$ 299$ \\
WA & $\$ 8839$ & $\$ 3395$ & $\$ 21,901$ & $\$ 6027$ & $\$ 6074$ \\
(high) per hectare & & & & \\
CA & $\$ 36,851$ & $\$ 1745$ & & $\$ 2409$ & \\
MI & $\$ 5342$ & $\$ 1594$ & $\$ 7762$ & $\$ 1517$ & $\$ 521$ \\
NY & $\$ 5869$ & $\$ 1374$ & $\$ 8362$ & $\$ 5893$ & $\$ 1695$ \\
OR & $\$ 4522$ & $\$ 4319$ & $\$ 4567$ & $\$ 2782$ & $\$ 670$ \\
WA & $\$ 10,957$ & $\$ 3546$ & $\$ 28,679$ & $\$ 7492$ & $\$ 6449$ \\
(low) statewide & & & & \\
CA & $\$ 44,768,942$ & $\$ 330,152,570$ & - & $\$ 19,043,392$ & - \\
MI & $\$ 33,056,603$ & $\$ 8,411,087$ & $\$ 3,897,156$ & $\$ 3,678,415$ & $\$ 3,564,496$ \\
NY & $\$ 2,022,599$ & $\$ 18,865,963$ & $\$ 2,396,463$ & $\$ 1,067,263$ & $\$ 945,958$ \\
OR & $\$ 11,114,600$ & $\$ 16,765,873$ & $\$ 146,590$ & $\$ 9,692,216$ & $\$ 78,479$ \\
WA & $\$ 16,837,524$ & $\$ 46,309,646$ & $\$ 80,637,058$ & $\$ 79,755,908$ & $\$ 3,680,536$ \\
(high) statewide & & & & \\
CA & $\$ 47,349,084$ & $\$ 345,390,381$ & - & $\$ 26,422,707$ & - \\
MI & $\$ 40,149,721$ & $\$ 9,163,517$ & $\$ 6,166,929$ & $\$ 4,244,325$ & $\$ 5,206,040$ \\
NY & $\$ 2,137,747$ & $\$ 20,592,260$ & $\$ 2,951,741$ & $\$ 1,347,325$ & $\$ 1,029,425$ \\
OR & $\$ 11,114,600$ & $\$ 20,206,427$ & $\$ 357,679$ & $\$ 12,132,214$ & $\$ 175,902$ \\
WA & $\$ 20,867,017$ & $\$ 48,345,235$ & $\$ 105,587,538$ & $\$ 99,155,994$ & $\$ 3,908,411$ \\
\hline & & & & & \\
\hline
\end{tabular}


Geographic differences in damage may be driven by many factors. Growers in certain regions may face an inherently greater threat from bird species, or the difference in damages may result from different production practices and bird management methods. Within a specific fruit crop, value may differ considerably by region. For example, prices received by California blueberry growers from 2008 to 2010 were nearly three times the average price received by Oregon growers. Price differences across regions may stem from variety and quality differences, as well as regional market conditions. Regardless of the source of such differences, value can have a significant effect on the incentive to manage damage. Reported damage to blueberries in Oregon was nearly double that in California, a difference that is likely a function of the difference in value. Growers in Oregon may be less likely to invest in effective bird management because they receive lower prices for their berries. Crop value and grower revenue influence the use of pest management techniques by affecting growers' ability to pay for it. Certain methods of bird damage management can be quite costly, and a grower must be confident in earning sufficient revenue to incur that cost.

Similarly, differences in damage across the five crops are a result of many factors. Certain crops are inherently more attractive to birds, and it may be more difficult to manage birds in some crops. For example, wine grapes and blueberries can be protected by netting more easily than crops such as apples and cherries. Whether a crop is intended for fresh market or processing may be another factor. Growers of crops such as tart cherries and apples intended for processing may be more tolerant of bird damage because imperfect fruit may still be marketable. Alternatively, fresh-market growers may be less tolerant of damage because damaged fruit is unmarketable.

The estimates of bird damage and the benefits of management provided by this analysis show that both have a significant impact on growers. Responses to supplementary survey questions indicated that a majority (56.7\%) of growers believed bird damage to be one of several significant factors that determine profitability; $6 \%$ believed bird damage was the most significant factor. Additionally, $22.7 \%$ of growers reported yield-loss in excess of $10 \%$. However, the impacts of bird damage are not limited to growers. Processors who purchase these fruits, and consumers who purchase the fresh fruit and derived products, are ultimately harmed by the higher prices they pay because of bird damage. The benefits of damage management are similarly not limited to grower profitability. Ultimately, it is the consumer that benefits by paying less for fruit and other food products when growers are able to employ effective bird management.

Bird damage-management benefits could be higher and costs to growers and consumers lower if more effective bird management techniques were available or if current techniques could be refined to increase their effectiveness. Most management techniques were classified by growers as ineffective, or only slightly effective. Netting, the technique ranked as most likely to be effective, is costly. Thus, our results point to the need for innovative solutions to bird management and refinement of techniques that currently exist.

There are several shortcomings of this analysis that should be noted. First, we relied on data provided by a survey of growers who may not have accurate perceptions of current levels of bird damage, or what damage would be without control. Additionally, the sample of growers that completed the survey may not be representative of all growers and the number of responses for some crops in some states is low, making reliance on those responses to form state-level estimates tenuous. In particular, results related to California and Oregon blueberries, Oregon and Washington tart cherries, and Oregon wine grapes should be interpreted with caution. There may also be varietal differences in bird damage that were not captured by our data. We were unable to follow up with many nonrespondents because we were not given direct access to grower contact information in all cases. Finally, few data are available on Honeycrisp apple production and prices, and we were forced to rely on estimates from multiple sources and make assumptions based on other types of apple production or outdated data.

The results of our analysis are useful for several reasons. First, by identifying which crops and regions are impacted by high levels of bird damage, researchers can more effectively focus limited resources. Growers also benefit by gaining a more complete understanding of how bird damage impacts other growers in their region, how damage varies across growing regions, and how beneficial management may be. Finally, policymakers and the public benefit by having a better understanding of both current bird damage to the selected crops and the benefits of its management. Some preventive methods of bird damage management are controversial (e.g., chemical repellents, auditory deterrents, or shooting), and their use heavily regulated. It is important that regulators and the public have accurate information about the benefits of managing birds in fruit crops if new regulations are considered or if resources are to be invested in developing new or more effective management techniques.

\section{Acknowledgments}

We wish to thank the following organizations for their assistance with survey implementation: New York Apple Association, New York Wine \& Grape Foundation, Cornell University Department of Horticulture, Ottawa County Michigan State University Extension, Michigan Apple Committee, Michigan Grape and Wine Industry Council, Cherry Marketing Institute, Good Fruit Grower Magazine, Washington Blueberry Commission, Washington Apple Commission, California Cherry Advisory Board, Oregon Sweet Cherry Commission, Oregon Wine Board, Columbia River GrowersShippers Association, Washington State University Viticulture \& Enology Program, California Blueberry Commission, California Association of Winegrape Growers, Oregon Wine Board, and Oregon Blueberry Commission.

\section{References}

Ahmad, S., 2010. Sustainable Control Measures for Rose-ringed Parakeet (Psittacula krameri) on Maize, Sunflower, Citrus, Guava and Mango Damage in Some Selected Agro-Ecosystems in Central Punjab, Pakistan. Ph.D. thesis. University of Agriculture, Faisalabad, Pakistan, p. 113.

Berge, A.J., Delwiche, M.J., Gorenzel, W.P., Salmon, T.P., 2007. Bird control in vineyards using alarm and distress calls. Am. J. Enol. Vitic 58 (1), 135-143.

Crase, F.T., Stone, C.P., DeHaven, R.W., Mott, D.F., 1976. Bird Damage to Grapes in the United States, with Emphasis on California. United States Department of the Interior, Fish and Wildlife Service, Washington, D.C., USA. Special Scientific Report - Wildlife No. 197.

Cummings, J.L., Shwiff, S.A., Tupper, S.K., 2005. Economic impacts of blackbird damage to the rice, industry. Pro. Wildl. Damage Manage. Conf. 11, 317-322.

DeHaven, R.W., 1974. Bird Damage to Seeds and Seedling Crops in California, a Questionnaire Survey. Technical Report No. 11, Work Unit DF-102.3. Denver Wildlife Research Center, U.S. Dept. of the Interior, Fish \& Wildlife Service.

Delwiche, M.J., Houk, A., Gorenzel, W.P., Salmon, T.P., 2007. Control of crows in almonds by broadcast distress calls. Trans. ASABE 50, 675-682.

Dillman, D.A., 2000. Mail and Internet Surveys: the Total Design Method, second ed. John Wiley \& Sons, New York, New York, USA.

Dolbeer, R.A., Holler, N.H., Hawthorne, D.W., 1994. Identification and control of wildlife, damage. In: Bookhout, T. (Ed.), Research and Management Techniques for Wildlife and Habitats. The Wildlife Society, Bethesda, Maryland, USA pp. 474-506.

Duffy, S., Schaffner, D.W., 2002. Monte Carlo simulation of the risk of contamination of, apples with Escherichia coli 0157:H7. Int. J. Food Microbiol. 78 (3), 245-255.

United States Department of Agriculture Economic Research Service (ERS), 2011. ERS Fruit and Nut Yearbook. http://usda.mannlib.cornell.edu/MannUsda/ viewStaticPage.do?url=http://usda01.library.cornell.edu/usda/ers/./89022/ 2010/index.html (accessed 15.06.12.). 
Food and Agriculture Organization of the United Nations (FAO), 2012. FAOSTAT. http://faostat3.fao.org/home/index.html\#HOME (accessed July 2012).

Gadd Jr., P., 1996. Use of the modified Australian crow trap for the control of depredating birds in, Sonoma County. Pro. Vert. Pest Conf. 17, 103-107.

Gebhardt, K., Anderson, A.M., Kirkpatrick, K., Shwiff, S.A., 2011. A review and synthesis of bird and, rodent damage to select California Crops. Crop Prot. 30 (9), 1109-1116.

Holb, I.J., Scherm, H., 2008. Quantitative relationships between different injury factors and, development of brown rot caused by Monilinia fructigena in integrated and organic apple orchards. Phytopathology 98 (1), 79-86.

Hothem, R.L., Mott, D.F., DeHaven, R.W., Guarino, J.L., 1981. Mesurol as a bird repellent on wine grapes in Oregon and California. Am. J. Enol. Vitic. 32 (2), 150-154.

Hueth, B.M., Cohen, D., Sangrujee, N., Zilberman, D., 1997. Economic Impact of Nonpredator Vertebrate Pest Damage in California Agriculture. Final report prepared for the California Department of, Food and Agriculture. Vertebrate Pest Control Research Advisory Council, Sacramento, CA, USA

United States Department of Agriculture National Agricultural Statistics Service (NASS), 1999. Fruit Wildlife Damage. http://usda01.library.cornell.edu/usda/ nass/fwd/wild0599.pdf (accessed 12.07.12.).

United States Department of Agriculture National Agricultural Statistics Service (NASS), 2006a. Oregon Fruit Tree Inventory Survey. http://www.nass.usda.gov/ Statistics_by_State/Oregon/Publications/Fruits_Nuts_and_Berries/FTI-2006.pdf (accessed 26.09.12).

United States Department of Agriculture National Agricultural Statistics Service (NASS), 2006b. New York Fruit Tree and Vineyard Survey. http://www.nass usda.gov/Statistics_by_State/New_York/Publications/Special_Surveys/FruitTree/ Fruit\%20Tree\%202006Revised.pdf (accessed 26.09.06.).

United States Department of Agriculture National Agricultural Statistics Service (NASS), 2012a. Michigan Rotational Survey: Fruit Inventory 2011-2012.
http://www.nass.usda.gov/Statistics_by_State/Michigan/Publications/ Michigan_Rotational_Surv, eys/mi_fruit12/apples.pdf (accessed 26.09.12.).

United States Department of Agriculture National Agricultural Statistics Service (NASS), 2012b. Noncitrus Fruits and Nuts 2011 Summary. http://usda01.library. cornell.edu/usda/current/NoncFruiNu/NoncFruiNu-07-06-2012.pdf (accessed 18.10.12.).

Pritts, M.P., 2001. Bye bye birdie: repelling birds from fruit plantings. N. Y. Fruit Q. 9 (4), 5-7.

Razee, D., April 17, 1976. California Agriculture Loses \$40 Million a Year From Vertebrate Pest Damage. California, Farmer, pp. 60-61.

Ribot, R.F.H., Berg, M.L., Buchanan, K.L., Bennett, A.T.D., 2011. Fruitful use of bioacoustic alarm stimuli as a deterrent for Crimson Roseallas (Playcercus elegans). Emu 111 (4), 360-367.

Simon, G., 2008. A short overview of bird control in sweet and sour cherry orchards - possibilities of, protection of bird damage and its effectiveness. Int. J. Hortic. Sci. $14(1-2), 107-111$.

Somers, C.M., Morris, R.D., 2002. Birds and wine grapes: foraging activity causes small-scale, damage patterns in single vineyards. J. Appl. Ecol. 39 (3), 511-523.

United States Department of Agriculture Economic Research Service (ERS), 2012 Fruit and Tree Nuts Background. http://www.ers.usda.gov/topics/crops/fruittree-nuts/background.aspx (accessed 18.10.12.)

United States Department of Agriculture National Agricultural Statistics Service, 2002. U.S. Wildlife Damage. http://usda01.library.cornell.edu/usda/current/ uswd/uswd-05-03-2002.pdf (accessed 12.07.12.).

Virgo, B.B., 1971. Bird damage to sweet cherries in the Niagara Peninsula, Ontario. Can. J. Plant Sci. 51 (5), 415-423.

Washington State University (WSU) Extension, 2011. 2011 Cost Estimates of Establishing, Producing, and Packing Honeycrisp Apples in Washington. Washington State University. Extension Fact Sheet FS062E. 